\title{
ВПЛИВ ПРОБІОТИКІВ НА МІКРОБІОЦЕНОЗ ШЛУНКОВО-КИШКОВОГО ТРАКТУ ТЕЛЯТ
}

\author{
Шкромада Оксана Іванівна \\ доктор ветеринарних наук, профресор \\ Сумський національний аграрний університет (м. Суми, Україна) \\ ORCID: 0000-0003-1751-7009 \\ oshkromada@gmail.com
}

Дудченко Юлія Андріївна

аспірант кафедри терапії, фрармакології, клінічної діагностики та хімії

Сумський національний аграрний університет (м. Суми, Україна)

ORCID:0000-0001-9243-8621

dudchenko.yulia@ukr.net

Удовенко Яна Сергіївна

асистент кафедри терапії, фрармакології, клінічної діагностики та хімії

Сумський національний аграрний університет (м. Суми, Україна)

ORCID:0000-0001-7260-3140,

f_vet@ukr.net

В роботі викладені результати дослідження про використання пробіотичних итамів мікроорганізмів для телят від народження до місяия. Пробіотики застосовуються у молочному господарстві для підвищення імунітету новонароджених телят та профілактики шлунково-кишкових розладів, збільшенню середньодобових приростів, зменшенню виробничих стресів, нормалізації мікробіоти. Метою роботи було визначити вплив пробіотичних итамів мікроорганізмів на мікробіоту шлунково-кишкового тракту телят. Дослідження проводили в умовах господарства ТОВ АФ «Хлібодар» с. Головашівка Сумського району Сумської області, в якому утримується велика рогата худоба різних технологічних груп. При вибірковому експерименті формували п'ять дослідних групи по п'ять тварин у кожній та одна - контрольна. Телятам дослідних груп випоювали разом з замінником молозива пробіотичні штами мікроорганізмів по 5 г на кожну тварину: Bacillus coagulans, Bacillus mucilaginosus, Bacillus megaterium, Bacillus pumilus, Bacillus amyloliquefaciense.

B. coagulans не сприяв росту лактобактерій - 7×104, однак добре зменшував кількість умовно патогенних мікроорганізмів роду Clostridium 101, порівняно з контрольною групою телят без пробіотика $3 \times 10^{1}$. В. mucilaginosus сприяв розмноженню Lactobacillus sp. до 8×106, порівняно до контрольної групи 1×105. Також пробіотик пригнічував ріст умовно патогенних мікроорганізмів роду Clostridium нижче 101. При випоюванні телятам B. mucilaginosus був відсутній picm Escherichia coli, які мають гемолітичну активність та зменшення загальної кількості Escherichia coli до 2×104. B. megaterium позити-

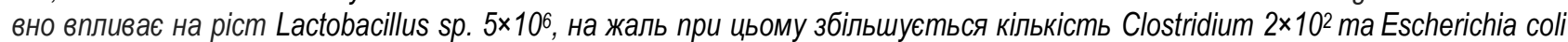
$6 \times 10^{4}$, порівняно з контрольною групою $3 \times 10^{1}-3 \times 10^{4}$ відповідно. В. ритіlus сприяє росту та розмноженню лакторбактерій $7 \times 10^{5}$, порівняно до контролю - 1×105. Пробіотик не значно пригнічує picm Clostridium ma Enterobacteriaceae. Hе знищує

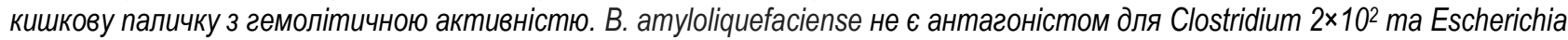
coli $6 \times 10^{4}$. B. amyloliquefaciense знищує гемолітичну кишкову паличку, однак при цьому збільшується ріст дріжджоподібних

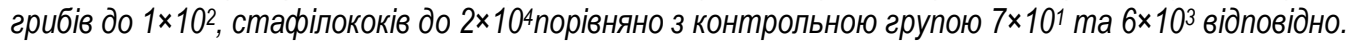

Бактерії родів Salmonella, Pseudomonas не були виявлені в фекальних масах телят дослідних та контрольних груп, що вказує на благополуччя господарства стосовно шлунково-кишкових захворювань бактеріального походження. Кількість біфідобактерій у всіх дослідних та контрольній групі було виявлено до 105. Проведені дослідження використання спороутворюючих пробіотичних штамів Bacillus spp. для телят доводять часткову ефекттивність кожного з них і дають підставу для створення комплексного пробіотичного засобу із залученням декількох штамів для отримання максимального ефекту.

Ключові слова: пробіотичні спороутворюючі штами Bacillus spp., телята, шлунково-кишкова мікрофрлора, жуйка, травлення

DOl:https://doi.org/10.32845/bsnau.vet.2020.1.1

Вступ. Інтенсифікація виробництва молочної промисловості призвела до збільшення вживання вуглеводистих кормів жуйними тваринами, що викликало збільшення випадків метаболічних розладів у вигляді ацидозу рубця. На фоні цих процесів відбувається зниження рН в рубці, порушення мікробіоти, і дисфуункція травлення. Інтоксикація організму пов'язана із зменшення продукування органічних кислот рубцевими мікроорганізмами, такими як Streptococcus bovis. Однак вплив кількості вуглеводів на мікроорганізми рубця не повність вивчений.
Раніше вважалось що ацидоз рубця можна профілактувати лише збалансованим раціоном. Штучним шляхом зменшували відсоток зерна, додаючи при цьому грубі корми до раціону. Однак одразу виникали проблеми, пов'язані з втратою продуктивності. Більшість технологій утримання передбачає використання декількох типів адаптаційних раціонів, які містять суміш зерна та кормові рослини у різних співвідношеннях. Такий механізм регулювання раціонів $€$ доволі ефрективним при контролюванні ацидозу, але він $€$ трудомістким, витратним та повільним.

Аналіз останніх досліджень і публікацій. Заборона 
у тваринництві на використання гормонів та антибіотиків для стимуляції росту призвела до необхідності використання безпечних кормових добавок у вигляді про біотичних штамів мікроорганізмів (Cheng et al ., 2014 ). Складання раціону для телят має важливе завдання забезпечити фізіологічно необхідними поживними речовинам. При цьому враховують вік тварин та технологію утримання. Одночасно з цим виникли ризики інфекційних захворювань у тварин (Hao et al . 2014).

Регуляція мікрофолори в рубці є необхідним елементом харчування для жуйних тварин. Експериментально доведено, що мікробіоцидоз шлунково-кишкового тракту великої рогатої худоби безпосередньо впливає на нормальне функціонування всіх систем організму (Basso et al.,2014; Tan et al., 2014).

Високотехнологічний сучасний спосіб утримання жуйних тварин зменшує їх контакт землею та водоймами, які $є$ джерелами корисної мікрофолори. Велике значення має технологія вирощування телят: разом з матір'ю та окремо в профрілакторіях (Shkromada, O., et al., 2019). Мікробіота рубця починає формуватись у телят одразу після народження, потрапляючи 3 навколишнього середовища. Нормальне повноцінне функціонування рубця у молодняка великої рогатої худоби стартує через шість тижнів (Kong et al., 2019; Liu et al., 2019.)

Через місяць використання ферментно-пробіотичної добавки на основі спороутворюючих Bacillus spp. телятам чисельність бактерій вірогідно збільшилась на 94,3 \%; інфузорій - на 40,5\%; ентодиноморфів - на $26, \%$, порівняно до контролю ( $\left.{ }^{*}<<0,001\right)$. Отримані дані реєстрації першої жуйки у телят доводять, що складові ферментно-пробіотичної добавки «Імунобакетрин- D» прискорюють заселення мікрофлорою та розвиток рубцевого травлення у телят у 2,5 рази, порівняно із телятами контрольної групи. Перспективи подальших досліджень полягають у дослідженні впливу ферментнопробіотичної добавки «Імунобакетрин- D» на показники рубцевої ферментації телят (Rybachuk et al., 2020).

Зараз використовують обмежену кількість пробіотиків у харчовій, медичній промисловості та тваринництві: Bifidobacterium, Lactobacillus, Bacillus subtilis та ін. Лактобактерії та Біфідобактерії наразі є популярними у використанні пробіотичні засоби. Недоліком цих штамів $є$ слабка термостабільність, чутливість до зміни рН, впливу травних ферметів та жовчних кислот (Ruiz et al., 2011).

Існують також технічні проблеми із зберіганням, використанням та механізмом їх доставки. Також Lactobacillus та Bifidobacterium не утворюють спор, які можна піддавати ліофільній сушці, що зменшує термін придатності про біотичних порошкоподібних засоби. (Govender et al., 2014)

В даний час використовуються в якості пробіотиків та дієтичних добавок кілька штамів Bacillus sp. (Mingmongkolchai et al., 2018)

Різні види Bacillus spp. все більше використовуються у міжнародній сільськогосподарській промисловості через властивість утворювати спори. За використання сучасних технологій можна виробляти спори пробіотиків для використання на виробництві, змішуючи їх з денним раціоном кормів для тварин. Наразі фармацевтичні компанії виробляють спори Bacillus sp., які витримують нагрівання до 80 C, слаболужне та слабокисле рН шлунково-кишкового тракту і не потребують спеціальних умов зберігання. (Kapse et al., 2018).

Кожний штам Bacillus spp. має свої властивості та специфічну дію на організм телят. Тому в цій роботі були проведений аналіз результатів використання Bacillus coagulans (Fijan, 2014), Bacillus mucilaginosus, Bacillus megaterium, Bacillus pumilus (Wu et al., 2014), Bacillus amyloliquefaciense (EFSA, 2014) для новонароджених телят.

Ферменти, такі як протеаза, пробіотичних штамів роду Bacillus мають властивості подібні до антимікробних засобів. Доведено, що Bacillus amyloliquefaciense (EFSA, 2014) може продукувати ферменти і антибіотики широкого спектру дії, які пригнічують ріст умовно-патогенної бактеріальної мікрофлори та мікроспорідіїв. Ізольовані протеази здатні лізувати живі клітини Aphylococcus aureus та Candida albicans.

Bacillus coagulans (B. coagulans) - факультативний грампозитивний спороутворюючий анаеробний, який виробляє молочну кислоту. Його називають королем пробіотиків через стійкість у шлунково-кишковому тракті до ферментів та відсутність токсичності. Але фармакологічний вплив на організм тварин $€$ недостатньо вивченим.

B. coagulans термостійкий; оптимальна температура для росту для $B$. coagulans становить від 35 до $50 \circ \mathrm{C}$, а оптимальна pH 5,5 - 6,5. Спори В. coagulans стійкі, стабільні, активуються в слабокислому середовищі шлунку, а потім проростають і розмножуватися в кишечнику. Bacillus coagulans у шлунково- кишковому тракті з відіграє роль молочнокислих бактерій (LAB) (Zhou et al., 2020).

Мета роботи. Метою роботи було визначити вплив пробіотичних штамів мікроорганізмів на мікробіоту шлунковокишкового тракту телят.

Матеріали і методи досліджень. Для дослідження були залучені п'ять дослідних груп телят по п'ять тварин у кожній, яким випоювали пробіотичні штами Bacillus spp. В контрольній групі пробіотики не задавали. Дослід проводили протягом одного місяця. Експеримент проводили в умовах ТОВ АФ «Хлібодар» с. Головашівка Сумського району Сумської області, в якому вирощують велику рогату худобу різних технологічних груп. Телятам дослідних груп одразу після народження випоювали разом з замінником молока пробіотики Bacillus spp. 3 розрахунку 5 грам на тварину. Всім телятам був забезпечений вільний доступ до якісного сіна та води. Від телят після завершення досліду були відібрані зразки фекалій.

3 метою встановлення мікробіоценозу кишечника у телят бактеріологічними методами проводили досліди на наявність патогенних колоній мікроорганізмів, лактобактерій, бактерій групи кишкової палички, сальмонел, сульфітредукуючих клостридій, стафрілококів, псевдомонад, біфрідобактерій, дріжджоподібних грибів, та інших бактерій 3 родини Enterobacteriaceae. Виявляли в фекальних масах мікроорганізми, які мають фактори патогенності, такі як лицитіназу, гемолізини та плазмокоагулазу. Проводили десятикратне розведення проб матеріалу та посів на селективні середовища. Після культивування мікроорганізмів підраховували кількість колонієутворюючих одиниць в 1 г фекалій (КУО/г).

Для виділення сальмонел та псевдомонад додатково робили висіви на середовища для накопичення даних мікроорганізмів, зокрема Магнієве середовище (для сальмонел) та середовище №8 (для псевдомонад), виробництва ФБУН ГНЦ та ТОВ «Фармактив». Видову належність ізольованих культур мікроорганізмів визначали за тестами, що рекомендовані у «Bergey's Mannual of Systematics Bacteriology», застосовували МПБ з феноловим червоним (Phenol Red 
Broth Base), для диференціальної діагностики мікроорганізмів диски та смужки виробництва «Himedia Laboratories Prv. Limited» (Індія). Суху цитратну плазму кролика використовували для визначення плазмокоагулази (виробництво ПАТ «Фармстандарт-Біолік» (Україна), гемолізинів - $5 \%$ кров'яний агар, лецитовітелази (лецитинази) - жовтково-сольовий агар.

Результати досліджень. Підтримка нормальної мікрофлори в рубці телят є дуже складним та важливим завданням у тваринництві. В перший місяць після народження у телят формується імунітет та мікрофлора шлунково-кишкового тракту. Важливим є ефективна робота елементів резистентності, де значну роль відіграє мікробіота шлунково-кишкового тракту тварини. Зменшення технологічного стресу, жорстке дотримання санітарних умов та якісна годівля сприяє у досягненні максимальних приростів та міцному здоров'ю тварин. Слід також зазначити, що у дослідному господарстві епізоотична ситуація благополучна стосовно інфекцій, які уражують шлунково-кишковий тракт молодняка великої рогатої худоби. Однак у тварин спостерігали періодичні випадки діареї. Використання пробіотиків для телят повинно сприяти вирішенню проблем пов'язаних з формуванню імунітету та формуванню мікробіоти шлунково-кишкового тракту (табл.).

Таблиця

Результати визначення мікробіоценозу кишечнику у телят

\begin{tabular}{|c|c|c|c|c|c|c|c|}
\hline \multirow{2}{*}{ № } & \multirow{2}{*}{$\begin{array}{l}\text { Показники, } \\
\text { в } 1 \mathrm{~cm}^{3}\end{array}$} & \multicolumn{6}{|c|}{ Телята } \\
\hline & & B. coagulans & B. mucilaginosus & B. megaterium & B. pumilus & B. amyloliquefaciense & Контроль \\
\hline 1 & $\begin{array}{c}\text { Лактобактерії } \\
\text { (Lactobacillus sp.) }\end{array}$ & $7 \times 10^{4}$ & $8 \times 10^{6}$ & $5 \times 10^{6}$ & $7 \times 10^{5}$ & $1 \times 10^{6}$ & $1 \times 10^{5}$ \\
\hline 2 & $\begin{array}{l}\text { Біфідобактерії } \\
\text { (Bifidobacterium) }\end{array}$ & $10^{5}$ & $10^{5}$ & $10^{5}$ & $10^{5}$ & $10^{5}$ & $10^{5}$ \\
\hline 3 & Бактерії роду Clostridium & $\begin{array}{c}\text { Нижче } \\
10^{1}\end{array}$ & $\begin{array}{c}\text { Нижче } \\
10^{1}\end{array}$ & $2 \times 10^{2}$ & $1 \times 10^{1}$ & $2 \times 10^{2}$ & $3 \times 10^{1}$ \\
\hline 4 & Escherichia coli & $1 \times 10^{2}$ & $2 \times 10^{4}$ & $6 \times 10^{4}$ & $9 \times 10^{4}$ & $6 \times 10^{4}$ & $3 \times 10^{4}$ \\
\hline 5 & $\begin{array}{c}\text { Escherichia coli, які } \\
\text { мають гемолітичну активність }\end{array}$ & + & немає & немає & + & немає & + \\
\hline 6 & $\begin{array}{c}\text { Умовно патогенні м/о з родини } \\
\text { Enterobacteriaceae (Citrobacter } \\
\text { Enterobacter, Klebsiella) }\end{array}$ & $\begin{array}{c}\text { Нижче } \\
10^{1}\end{array}$ & $2 \times 10^{2}$ & $\begin{array}{l}\text { Нижче } \\
10^{1}\end{array}$ & $4 \times 10^{2}$ & $2 \times 10^{2}$ & $6 \times 10^{2}$ \\
\hline 7 & Salmonella & немає & немає & немає & немає & немає & немає \\
\hline 8 & Pseudomonas & немає & немає & немає & немає & немає & немає \\
\hline 9 & Дріжджоподібни гриби & $3 \times 10^{1}$ & $3 \times 10^{2}$ & $4 \times 10^{2}$ & $3 \times 10^{2}$ & $1 \times 10^{2}$ & $7 \times 10^{1}$ \\
\hline 10 & Стафілококи & $8 \times 10^{3}$ & $1 \times 10^{4}$ & $4 \times 10^{4}$ & $3 \times 10^{4}$ & $2 \times 10^{4}$ & $6 \times 10^{3}$ \\
\hline 11 & $\begin{array}{c}\text { Стафрілококи, які мають гемолітичні } \\
\text { властивості }\end{array}$ & немає & немає & немає & немає & немає & немає \\
\hline 12 & $\begin{array}{c}\text { Стафілококи, які мають лицитіназну } \\
\text { активність } \\
\end{array}$ & немає & немає & немає & немає & немає & + \\
\hline 13 & $\begin{array}{c}\text { Стафілококи, які мають } \\
\text { плазмокоагулазну активність }\end{array}$ & немає & немає & немає & немає & немає & немає \\
\hline
\end{tabular}

Результати, отримані в ході експерименту, доводять, що випоювання телятам дослідної групи B. coagulans не сприяє росту лактобактерій - 7×104. Однак $B$. coagulans добре зменшує кількість умовно патогенних мікроорганізмів роду Clostridium 101, порівняно з контрольною групою телят без пробіотика $3 \times 10^{1}$. Проте, B. coagulans не знищували бактерії Escherichia coli, які мають гемолітичну активність,. Кишкова паличка з гемолітичною активністю за умов низької кількості біфідо- і лактобактерій може бути причиною шлунково-кишкових розладів. Крім того може набувати біоагресивності, долати захисні бар'єри господаря та спричиняти системні захворювання. Кількість Escherichia coli складала 1х102, порівняно до контрольної групи $3 \times 10^{4}$. Умовно патогенні мікроорганізми з родини Enterobacteriaceae (Citrobacter , Enterobacter, Klebsiella) в фекаліях телят дослідної групи, яким випоювали B. coagulans було на рівні 1012, що значно нижче, ніж у контролі - 6×1022. Стафілококи, які мають гемолітичні властивості, лицитіназну та плазмокоагулазну активніст,ь також не були виявлені в пробах фекалій отриманих від дослідних тварин. Дріжджоподібни гриби були виявлені в кількості 3×101, порівняно до контрольної групи - 7×101.

При проведенні експерименту клінічні показники телят: пульс, температура, частота дихання та скорочення рубця були в межах фізіологічної норми (Izuddin et al., 2020), тварини мали добрий апетит.

B. mucilaginosus сприяв розмноженню Lactobacillus spp. до $8 \times 10^{6}$, порівняно до контрольної групи $1 \times 10^{5}$. Також пробіотик пригнічував ріст умовно патогенних мікроорганізмів роду Clostridium нижче 101. При випоювання телятам $B$. mucilaginosus був відсутній ріст штамів Escherichia coli, які мають гемолітичну активність, та зменшення загальної кількості Escherichia coli до 2х104. Дріжджоподібни гриби були виявлені в кількості $3 \times 10^{2}$, що більше, ніж в контролі - 7×101. В. mucilaginosus не пригнічував ріст стафілококів $1 \times 10^{4}$. Кількість умовно патогенних мікроорганізмів 3 родини Enterobacteriaceae (Citrobacter, Enterobacter, Klebsiella) в фрекаліях телят дослідної групи, яким випоювали B. coagulans, була на рівні $2 \times 10^{2}$, що з нижче, ніж у контролі - 6x102.

B. megaterium позитивно впливає на ріст Lactobacillus spp., збільшуючи їх число до 5×106. Нажаль, при цьому збільшується кількість бактерій роду Clostridium до 2х102 та Escherichia coli - 6x104, порівняно з контрольною групою 3×101 та $3 \times 10^{4}$ відповідно. B. megaterium не зменшує ріст дріжджоподібних грибів $4 \times 10^{2}$ та стафілококів $4 \times 10^{4}$. Пробіотичний штам здатний знищувати кишкову паличку з гемолітичними властивостями. Кількість мікроорганізмів 3 родини Enterobacteriaceae (Citrobacter, Enterobacter, Klebsiella) при застосуванні $B$. megaterium зменшилось до101, що значно 
нижче, ніж у контролі - 6×10².

B. pumilus сприяє росту та розмноженню лакторбактерій $7 \times 10^{5}$, порівняно до контролю - $1 \times 10^{5}$. Не значно пригнічує ріст Clostridium ma Enterobacteriaceae. Не знищує кишкову паличку з гемолітичною активністю. Збільшується ріст кишкової палички, стафрілококів та дріжджоподібних грибів, порівняно 3 контролем.

B. amyloliquefaciense створював сприятливі умови для росту Lactobacillus sp. $1 \times 10^{6}$. Пробіотик не $є$ для антагоністом для Clostridium $2 \times 10^{2}$ та Escherichia coli $6 \times 10^{4}$ B. amyloliquefaciense знищує гемолітичну кишкову паличку, однак при цьому збільшується ріст дріжджоподібних грибів до $1 \times 10^{2}$, стафрілококів до $2 \times 10^{4}$ порівняно 3 контрольною групою $7 \times 10^{1}$ та $6 \times 10^{3}$ відповідно.

Бактерій Salmonella, Pseudomonas не були виявлені в фекальних масах телят дослідних та контрольних груп, що вказує на благополуччя господарства стосовно шлунково-кишкових захворювань бактеріального походження. Кількість біфідобактерій у всіх дослідних та контрольній групі було виявлено до $10^{5}$.

Обговорення. У рубці великої рогатої худоби створені оптимальні умови для існуванні мікрофлори - це рН та постійна температура тіла. Мікробіота шлунково-кишкового тракту бере участь у метаболізмі вуглеводів, ліпідів, жирів та білків, які містяться потрапляють з кормом (Silva et al., 2016; Soares et al., 2017).

Дисбаланс кислотності або зміна температурного балансу може призвести до зменшення або загибелі значної частини мікрофрлори шлунково-кишкового тракту жуйних (Fan et al., 2015). Основою раціону жуйних тварин $€$ корма рослинного походження і тому целюлозні бактерії мають значну роль у травленні (Aikman et al., 2010; Stover et al., 2017). Kрохмаль є важливим джерелом енергії у кормах телят. Використання концентрованих зернових кормів у раціоні дуже ефективне для стимуляції росту та розвитку тварин, але вони можуть порушувати метаболізм.

Порушення мікробіоценозу шлунково-кишкового тракту телят веде до порушення процесів абсорбції, запалення слизової оболонки кишечнику. На фоні виникнення інтоксикації організму виникають ентерит, діарея порушення водно-сольового балансу організму. Одним з шляхів подолання цієї проблеми можуть бути пробіотичні мікроорганізми.

Дослідники намагалися реалізувати замість адаптаційних кормів та інших складних схем раціонів застосовувати пробіотичні штами спороутворюючих мікроорганізмів Bacillus spp. Бацилюси зменшують утворення молочної кислоти в рубці за рахунок пригнічення мікроорганізмів Streptococcus bovis и Lactobacillus spp.

Безпосереднє введення пробіотичних мікроорганізмів для регуляції мікробіоти шлунково-кишкового тракту та підвищення продуктивності тварин набуло максимального поширення протягом останніх 10 років. Існують два основних шляхи введення мікроорганізмів, які можливі для використання в молочному скотарстві для контролю мікробіоти шлунково-кишкового тракту та рН рубця: перший - застосування мікроорганізмів, які виробляють молочну кислоту, і другий використання пробіотичних штамів бактерій, здатних використовувати молочну кислоту.

В першому випадку, використання таких видів мікроорганізмів як Enterococcus, призводить до збільшення молоч- ної кислоти в рубці. Поступово відбувається адаптація мікробіоти шлунково-кишкового тракту. Однак ці заходи не забезпечують надійного контролю ацидозу та не запобігають пригніченню умовно-патогенної мікрофлоори.

3 іншого боку, ефективним є додавання безпосередньо специсфічних видів пробіотичних штамів сороутворюючих мікроорганізмів таких як Bacillus spp, які здатні до використання молочної кислоти для свого метаболізму і тим самим знижують її вміст у рубці (Diao et al., 2017; Sun et al., 2010).

Дослідниками доведено, що B. coagulans може виробляти бактеріцид, який має назву коагулін. Також треба вказати, що вказаний штам не здатний закріплюватись на епітелії кишечника і повністю виводиться з організму через чотири-п'ять діб, якщо його періодично не вводити в організм. Тому B. coagulans необхідно тривалий термін застосовувати для того щоб отримати максимальний пробіотичний ефект (Shinde et al., 2019).

Треба відмітити, що В. mucilaginosus та B. megaterium найкраще спрацювали в якості пробіотиків для телят у даному дослідному господарстві. Всі дослідження проводили у порівнянні із контрольними тваринами без застосування будь яких засобів, які б могли вплинути на формування їх мікрофлори. Однак треба зазначити, що $B$. mucilaginosus та $B$. megaterium виступали як слабкі антагоністи стосовно стафілолкоків та Escherichia coli, порівняно із іншими Bacillus spp. За даними багатьох науковців та практикуючих лікарів з'ясовано, що в кожному окремому господарстві циркулює своя мікрофрлора і підбір пробіотиків необхідно проводити індивідуальним способом з урахуванням специфіки кожного господарства.

Пробіотичний штам $B$. coagulans добре зменшує кількість умовно патогенних мікроорганізмів роду Clostridium, Escherichia coli та дріжджоподібних грибів. Також потрібно уточнити, що пробіотичні штами Bacillus spp. пригнічують умовно патогенну мікрофолору, не впливаючи на іншу. Таким чином знищуючи наприклад колонії Escherichia coli, ми провокуємо збільшення колоній дріжджоподібних грибів.

B. pumilus та $B$. amyloliquefaciense не проявили достатньої ефрективності для пригнічення умовно-патогенної мікрофрлори у шлунково-кишковому тракті телят. Дещо збільшилась кількість лактобактерій, але також збільшився ріст кишкової палички, стафілококів та дріжджоподібних грибів, порівняно з контролем.

Тому, на основі проведеного експерименту, треба зазначити, що використання в господарстві одного пробіотичного штаму Bacillus spp. буде помилковим. Необхідно визначитись із комплексом пробіотичних штамів, які будуть доповнювати один одного. Перспектива подальшого дослідження: формування комплексу спороутворюючих пробіотичних штамів Bacillus spp. для використання у господарствах з вирощування молодняка великої рогатої худоби.

\section{Висновки.}

1. За результатами бактеріологічних досліджень вмісту кишечнику у телят було виявлено кількість лактобактерій у межах від $7 \times 10^{4}$ до 2×107; рівень біфідобактерій у межах 105; наявність кишкових паличок з гемолітичними властивостями у телят контрольної групи та дослідних із застосуванням $B$. coagulans та B. pumilus.

2. Використання спороутворюючих пробіотичних штамів Bacillus spp. для телят доводять часткову ефективність кожного з них і дають підставу для створення комплексного 
пробіотичного засобу із залученням декількох штамів для | отримання максимального ефеекту.

\section{References:}

1. Cheng, G., Hao, H., Xie, S., Wang, X., Dai, M., Huang, L. and Yuan, Z. (2014) Antibiotic alternatives: the substitution of antibiotics in animal husbandry? Front Microbiol 5, 69- 83. https://doi.org/10.3389/fmicb.2014.00217

2. Hao, H., Cheng, G., Iqbal, Z., Ai, X., Hussain, H. I., Huang, L., Dai, M., Wang, Y., Liu, Z., \& Yuan, Z. (2014). Benefits and risks of antimicrobial use in food-producing animals. Frontiers in microbiology, 5, 288. https://doi.org/10.3389/fmicb.2014.00288.

3. Basso, F.C., Adesogan, A.T., Lara E.C., Rabelo, C. H. S., Berchielli, T. T., Teixeira, I. A. M. A., Siqueira, G. R., Reis, R. A. (2014). Effects of feeding corn silage inoculated with microbial additives on the ruminal fermentation, microbial protein yield, and growth performance of lambs. J Anim Sci. 92(12),5640-5650. https://doi.org/10.2527/jas.2014-8258

4. Tan, J., McKenzie, C., Potamitis, M., Thorburn, A.N., Mackay, C.R., Macia, L. (2014). The role of short-chain fatty acids in health and disease. Adv Immunol. 121, 91-119.

5. https://doi.org/10.1016/B978-0-12-800100-4.00003-9

6. Shkromada, O., Palii, A., Palii, A., Skliar, O., Dudchenko, Y., \& Necherya, T. (2019). Improvement of milk quality for micro-climate formation on cattle farms. Bulletin of Sumy National Agrarian University. The Series: Veterinary Medicine, (4 (47), 4349. https://doi.org/10.32845/bsnau.vet.2019.4.7

7. Kong, L., Yang, C., Dong, L., Diao, Q., Si, B., Ma, J., \& Tu, Y. (2019). Rumen Fermentation Characteristics in Pre- and Post-Weaning Calves upon Feeding with Mulberry Leaf Flavonoids and Candida tropicalis Individually or in Combination as a Supplement. Animals : an open access journal from MDPI, 9(11), 990. doi.org/10.3390/ani9110990

8. Liu, X., Zhao, W., Yu, D., Cheng, J. G., Luo, Y., Wang, Y., Yang, Z. X., Yao, X. P., Wu, S. S., Wang, W. Y., Yang, W., Li, D. Q., \& Wu, Y. M. (2019). Effects of compound probiotics on the weight, immunity performance and fecal microbiota of forest musk deer. Scientific reports, 9(1), 19146. doi.org/10.1038/s41598-019-55731-5

9. Rybachuk, Z., Shkromada, O., Predko, A., \& Dudchenko, Y. (2020). Influence of probiotics "Immunobacterin-D" on biocenoses and development of the gastrointestinal tract of calves. Scientific Messenger of LNU of Veterinary Medicine and Biotechnologies. Series: Veterinary Sciences, 22(98), 22-27. https://doi.org/10.32718/nvlvet9804

10. Ruiz, L., Ruas-Madiedo, P., Gueimonde, M., de Los Reyes-Gavilán, C. G., Margolles, A., \& Sánchez, B. (2011). How do bifidobacteria counteract environmental challenges? Mechanisms involved and physiological consequences. Genes \& nutrition, $6(3)$, 307-318. https://doi.org/10.1007/s12263-010-0207-5

11. Govender, M., Choonara, Y. E., Kumar, P., du Toit, L. C., van Vuuren, S., \& Pillay, V. (2014). A review of the advancements in probiotic delivery: Conventional vs. non-conventional formulations for intestinal flora supplementation. AAPS PharmSciTech, 15(1), 29-43. https://doi.org/10.1208/s12249-013-0027-1

12. Mingmongkolchai, S., \& Panbangred, W. (2018). Bacillus probiotics: an alternative to antibiotics for livestock production. Journal of applied microbiology, 124(6), 1334-1346. https://doi.org/10.1111/jam.13690

13. Kapse, N. G., Engineer, A. S., Gowdaman, V., Wagh, S., \& Dhakephalkar, P. K. (2019). Functional annotation of the genome unravels probiotic potential of Bacillus coagulans HS243. Genomics, 111(4), 921-929. https://doi.org/10.1016/i.ygeno.2018.05.022

14. Fijan S. (2014). Microorganisms with claimed probiotic properties: an overview of recent literature. International journal of environmental research and public health, 11(5), 4745-4767. https://doi.org/10.3390/ijerph110504745

15. Wu, H.J., Sun, L.B., Li, C.B., Li, Z.Z., Zhang, Z., Wen, X.B., Hu, Z., Zhang, Y.L. (2014) Enhancement of the immune response and protection against Vibrio parahaemolyticus by indigenous probiotic Bacillus strains in mud crab (Scylla paramamosain). Fish Shellfish Immunol 41, 156- 162. https://doi.org/10.1016/.fsi.2014.08.027

16. EFSA (2014) Guidance on the assessment of the toxigenic potential of Bacillus species used in animal nutrition. EFSA J 12, 3665. https://doi.org/10.2903/i.efsa.2014.3665

17. Zhou, Y., Zeng, Z., Xu, Y., Ying, J., Wang, B., Majeed, M., Majeed, S., Pande, A., \& Li, W. (2020). Application of Bacillus coagulans in Animal Husbandry and Its Underlying Mechanisms. Animals : an open access journal from MDPI, 10(3), 454. https://doi.org/10.3390/ani10030454

18. Izuddin, W. I., Humam, A. M., Loh, T. C., Foo, H. L., \& Samsudin, A. A. (2020). Dietary Postbiotic Lactobacillus plantarum Improves Serum and Ruminal Antioxidant Activity and Upregulates Hepatic Antioxidant Enzymes and Ruminal Barrier Function in Post-Weaning Lambs. Antioxidants (Basel, Switzerland), 9(3), 250. doi.org/10.3390/antiox9030250

19. Silva, L.D.D., Pereira, O.G., Silva, T.C.D., Valadares Filho, S.C., Ribeiro, K.G. (2016) Effects of silage crop and dietary crude protein levels on digestibility ruminal fermentation, nitrogen use efficiency, and performance of finishing beef cattle. Anim Feed Sci Technol. 220, 22-33. https://doi: 10.1016/j.anifeedsci.2016.07.008.

20. Soares, M.S., Oliveira, P.S., Debom, G.N., DaSilveira, M.B., Polachini, C.R., Baldissarelli, J., et al. (2017). Chronic administration of methionine and/or methionine sulfoxide alters oxidative stress parameters and ALA-D activity in liver and kidney of young rats. Amino Acids. 49(1), 129-138. https://doi.org/10.1007/s00726-016-2340-y.

21. Fan, P., Li, L., Rezaei, A., Eslamfam, S., Che, D., Ma, X. (2015). Metabolites of dietary protein and peptides by intestinal microbes and their impacts on the gut. Curr Protein Pept Sci. 16, 646-654. https://doi.org/10.2174/1389203716666150630133657.

22. Aikman, P.C., Henning, P.H., Humphries, D.J., Horn, C.H. (2010). Rumen pH and fermentation characteristics in dairy cows supplemented with Megasphaera elsdenii NCIMB 41125 in early lactation. J. Dairy Sci. 94, 2840-2849. https://doi.org/10.3168/jds.2010-3783

23. Stover, P.J., Durga, J., Field, M.S. (2017). Folate nutrition and blood-brain barrier dysfunction. Curr Opin Biotechnol. 44, 
146-152. https://doi.org/10.1016/i.copbio.2017.01.006.

24. Diao, Q., Zhang, R., Tu, Y. (2017). Current research progresses on calf rearing and nutrition in China. J. Integr. 16, 2805-2814. https://doi.org/10.1016/S2095-3119(17)61767-2

25. Sun, P., Wang, J.Q., Zhang, H.T. (2010). Effects of Bacillus subtilis natto on performance and immune function of preweaning calves. J Dairy Sci. 93(12), 5851-5855. https://doi.org/10.3168/jds.2010-3263

26. Shinde, T., Vemuri, R., Shastri, M.D., Perera, A.P., Tristram, S., Stanley, R., Eri, R. (2019). Probiotic Bacillus coagulans MTCC 5856 spores exhibit excellent in-vitro functional efficacy in simulated gastric survival, mucosal adhesion and immunomodulation. J. Funct. Foods, 52, 100-108. https://doi.org/10.1016/i.jf.2018.10.031.

O.I. Shkromada, Dr. Vet. Sciences, Professor, Sumy National Agrarian University (Sumy, Ukraine)

Yu.A. Dudchenko, PhD student, Sumy National Agrarian University (Sumy, Ukraine)

Ya. S. Udovenko, Assistant Sumy National Agrarian University (Sumy, Ukraine)

Probiotic effect on a gastrointestinal microbiocenosis of calves

The article presents studies about probiotic strains for calves from birth to one month of age. Probiotics are used in dairy farming to increase the immunity of newborn calves and prevent gastrointestinal disorders, increase average daily gain, reduce production stress, normalize the microbiota. The aim of the study was to determine the effect of probiotic strains of calves gastrointestinal microbiota. The research was carried out in the farm «Hlibodar» (village Golovashivka of Sumy district, Sumy region) with different technological groups of cattle management. In an experiment were formed five experimental groups of five animals each and one control group. Experimental groups were fed 5 grams of probiotic strains in the following composition per animal: Bacillus coagulans, Bacillus mucilaginosus, Bacillus megaterium, Bacillus pumilus, Bacillus amyloliquefaciense.

B. coagulans did not promote the growth of lactobacilli $7 \times 10^{4}$ (volumetric datum), but well reduces the number of opportunistic pathogens of the genus Clostridium 101, compared with the control group of calves without probiotic 3×101.

B. mucilaginosus contributed to the reproduction of Lactobacillus $\mathrm{sp}$. up to $8 \times 10^{6}$, compared to the control group $1 \times 10^{5}$. The probiotic inhibited the growth of the genus Clostridium below the average 101. Feeding of $B$. mucilaginosus reduced the amount of Escherichia coli to $2 \times 10^{4}$.

B. megaterium has a positive effect on the growth of Lactobacillus sp. $5 \times 10^{6}$, but increases the amount of Clostridium $2 \times 10^{2}$ and Escherichia coli $6 \times 10^{4}$, compared with the control group $3 \times 10^{1}$ and $3 \times 10^{4}$ respectively.

B. pumilus promotes the growth and reproduction of lactobacilli $7 \times 10^{5}$, compared to the control $-1 \times 10^{5}$. The probiotic does not significantly inhibit the growth of Clostridium and Enterobacteriaceae. The probiotic does not destroy Escherichia coli with hemolytic activity.

B. amyloliquefaciense is not an antagonist for Clostridium 2×102and Escherichia coli $6 \times 10^{4}$. B. amyloliquefaciense destroys hemolytic Escherichia coli, but increases the growth of yeasts to $1 \times 10^{2}$, staphylococci to $2 \times 10^{4}$ compared with the control group $7 \times 10^{1}$ and $6 \times 10^{3}$, respectively.

Bacteria Salmonella and Pseudomonas were not detected in the calves fecal masses of the experimental and control groups, it indicates the well-being of the farm as regards bacterial gastrointestinal diseases. The number of bifidobacteria in all experimental and control groups were detected up to $10^{5}$. Studies of Bacillus sp. probiotic strains prove the partial effectiveness of each of them and give grounds for the creation of a complex probiotic to have an optimum effect for calves.

Key words: probiotic spore-forming strains of Bacillus sp., calves, gastrointestinal microflora, cut-chewing, digestion.

Дата надходження до редакції: 20.12.2019 р. 